Review

\title{
A Systematic Review of the Existing Literature for the Evaluation of Sustainable Urban Projects
}

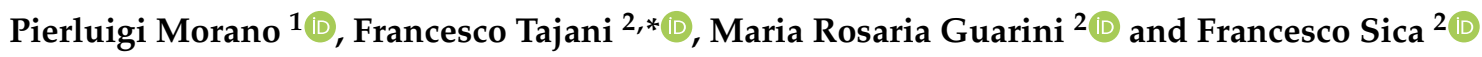 \\ 1 Department of Civil, Environmental, Land, Building Engineering and Chemistry, Polytechnic of Bari, \\ 70125 Bari, Italy; pierluigi.morano@poliba.it \\ 2 Department of Architecture and Design, Sapienza University of Rome, 00196 Rome, Italy; \\ mariarosaria.guarini@uniroma1.it (M.R.G.); francesco.sica@uniroma1.it (F.S.) \\ * Correspondence: francesco.tajani@uniroma1.it
}

check for updates

Citation: Morano, P.; Tajani, F.; Guarini, M.R.; Sica, F. A Systematic Review of the Existing Literature for the Evaluation of Sustainable Urban Projects. Sustainability 2021, 13, 4782. https://doi.org/10.3390/su13094782

Academic Editor:

Jose Navarrp-Pedreño

Received: 9 April 2021

Accepted: 22 April 2021

Published: 24 April 2021

Publisher's Note: MDPI stays neutral with regard to jurisdictional claims in published maps and institutional affiliations.

Copyright: (c) 2021 by the authors. Licensee MDPI, Basel, Switzerland. This article is an open access article distributed under the terms and conditions of the Creative Commons Attribution (CC BY) license (https:// creativecommons.org/licenses/by/ $4.0 /)$.

\begin{abstract}
From the 21st century to the present(2021), a worldwide awareness that cities' development must be based on projects for socio-economic growth and environmental protection is increasing. World governmental agencies and the European Union have suggested action strategies for the construction of «prototype cities» whose value must be founded on the inclusion and/or preservation of anthropic-natural elements and their effects on territories. In order to minimize the theoreticalpractical gap between planning and project design with a view to sustainable development and the evaluation of their performance from economic, social and environmental points of view, the present contribution aims to outline a framework useful for systematizing the main scientific contributions concerning sustainability and the evaluation of urban transformation projects. The objective is pursued by analyzing bibliographic references with specific regard to the use of logical-operative methodologies used to rationalize the processes of interventions' evaluation and selection. The task of examining the available literature is carried out with an investigation protocol of four sequential steps. From the implementation of the last one, the evidence expressing the heterogeneity of the examples in the literature is described. Accordingly, the theoretical-methodological framework for the project evaluation from an urban sustainability perspective is illustrated.
\end{abstract}

Keywords: sustainability; urban projects; economic evaluation; existing literature review; bibliographic survey protocol

\section{Introduction}

The phenomena of rapid climate change, uncontrolled cities' growth, migration and population density in highly urbanized areas have resulted in the impoverishment of the existing natural and built environment [1]. Urbanization, expansion and irregular transformation of built provided spaces have replaced agricultural, natural or semi-natural surfaces [2]. This has impacted the environmental, social and economic quality of territories [3]. Even the use of planning tools to support settlement models characterized by high land consumption and design logics based on conforming to dimensional and technical standards has produced territorial portions with inconsistent morphological, environmental, functional, productive and socio-cultural features. As specified in Privitera (2016), “(...) the processes of metropolization and urban dispersion, favored by low-density settlement models and high land consumption, have caused the loss of most of the semi-natural areas, determining a general decrease (...) in the quality of urban ecosystems". As a consequence, “(...) areas (...) with different values of ecological integrity, with different levels of proximity and intermingling with infrastructures or settlements, on which often incoherent urban planning forecasts, conditioning urban rents, uncontrollable densities and demographic dynamics have been created" [4].

In a scenario of this kind, there is an essential requirement to operate, especially in highly anthropic areas, by taking into account economic, social and environmental 
inequalities that characterize the same urban ecosystem, and thus to implement actions that encourage both economic growth and the protection of existing natural and environmental resources, as well as the protection of the citizens' well-being and psycho-physical health $[5,6]$ (in other words, actions capable of promoting sustainable development and integrated city growth).

From the second half of the 20th century onwards, international and European institutions proposed guidelines with specific regard to urban sustainability. In 1987, the World Commission on Environment and Development suggested “(...) sustainable urban development should ensure that the needs of present generations are met without compromising the ability of future generations to meet their own needs" [7]. In 1991, the World Conservation Union stated that "for urban development to be sustainable, it must ensure an improvement in the quality of life, without exceeding the carrying capacity of the underlying urban ecosystems" [8].

In some European countries, such as Finland and Belgium, actions to safeguard existing natural capital are implemented as strategic resource for sustainable city development [9]. This is also in response to the programmatic provisions of the Thematic Strategy for the Urban Environment [10] and is at the basis of some European Concerted Research Actions, such as the COST Action E12 (2005) "Urban Forests and Trees" [11] and the COST Action E39 (2006) "Forests, Trees and Human Health and Well-Being" [12].

In 2007, with the Leipzig Charter on Sustainable European Cities and Towns, the European Commission defined the set sustainable goals to be pursued in the European member states with specific measures aimed at revitalizing cities by acting not only on the built environment but also on society, the economy, culture and the environment [13]. In 2015, the United Nations (UN) approved the Global Agenda for Sustainable Development, which defined 17 Sustainable Development Goals (SDGs) that member states agreed to pursue by 2030. Among them, the SDG 11 aimed at "(...) making cities and human settlements inclusive, safe, resilient and sustainable by improving the quality of the environment and safeguarding the natural, cultural and social capital of the city" [14], which is of particular interest for urban regeneration actions. To date, the European Green New Deal strategy is guiding the development policies of the member states towards the goals of ecological transition and the de-carbonization of cities with measures aimed at making energy production more sustainable and improving citizens' lifestyles.

\section{Literature Review}

The focus on sustainability issues in the urban context has generated a growing number of publications in the literature characterized by innovative use of multiple, and often integrated, methods and tools to support the pursuit of economic, social and environmental growth objectives in cities. In some references, for the purpose of an easier and more immediate implementation of sustainability at urban and territorial scales, thematic maps have been produced, including assessment techniques, geo-spatial analysis tools and methodologies based on the use of performance indicators linked to the 2030 Agenda. The definition and use of thematic maps for evaluation practices' realization in the name of the transparency and formulation of effective and rational judgments is found to have been activity carried out in support of real estate valuations [15-17]; an analysis of the effects of urban transformation interventions on real estate values [18]; investments risk assessment $[19,20]$; auditing of the civil and environmental engineering constructions financial feasibility [21]; soil sealing [22]; urban sprawl detection and monitoring actions [23,24]; and complex decision-making systems based on multiple judgement criteria of various kinds [25].

In other literary studies, however, more than the use of maps and spatial information systems, one also finds the definition and application of composite indicators, i.e., indices, for measuring the overall level of sustainable well-being representative of the urban quality in the city. These indices reflect not only the productive capacity of places (generally expressed through the macro-economic indicator of gross domestic product (GDP)), but also 
take into account the specific urban ecosystem features (e.g., the amount of green space) and the existing socio-cultural system. In general, these are evaluation parameters used in urban economic-environmental analyses. Among the best-known indices in the literature there are the Ecological Footprint [26], Environmental Sustainability Index [27], Environmental Performance Index [28], European Green Cities Index [29], Genuine Savings [30], Human Development Index [31], Index of Sustainable Economic Welfare [32], Genuine Progress Indicator [33] and Well Being Index [34]. The main fields of use for these indices are in two main research areas. The first one checks atmosphere, water, soil and energy systems in relation to the components at the scale of city, province, region and state [35]. The second one examines the development policies of territorial contexts (urban, transport, tourism, and cultural policies) for monitoring their effects and resilience over time [36-38].

In order to minimize the theoretical-practical gap between the planning and design of sustainable development interventions and the assessment of the performance of each intervention from economic, social and environmental points of view, i.e., according to the dimensions of sustainability, this paper intends to outline a framework useful for systematizing the main scientific contributions concerning sustainable development and its achievement in an urban context. The objective is pursued by analyzing the bibliographic references with specific regard to the use of logical-operative methodologies with which to rationalize the evaluation and selection of interventions processes to be implemented considering economic, social and environmental targets. The proposed bibliographic survey pursues the multiple objectives of providing the state of the art (i) on the main scientific contributions regarding sustainability and economic evaluation of urban interventions; and (ii) on the evaluation methodologies and tools implemented to measure the performance characteristics of urban projects in sustainable way. The process of collecting, cataloguing and examining the existing literature is made according to an appropriate investigation protocol that consists of sequential steps. From the implementation of the proposed protocol, the evidence expressing the heterogeneity of the examples in literature is described. Accordingly, a theoretical-methodological framework for the evaluation and selection of interventions from an urban sustainability perspective is defined. The last one will express logical and operative actions to support a preliminary sustainable assessment for projects management in urban contexts. On the basis of it, the novelty of the current review is placed. In an attempt to reduce the possible gap between experience-based research and practical requirements related to urban project assessment, the systematic analysis of existing literature provides theoretical, methodological and operative support to public and private operators in the act of evaluating initiatives, in accordance with their financial interests and in compliance with economic, social and environmental sustainability principles as declared in the Agenda 2030.

The paper is structured in the following sections. Section 3 (Method) illustrates the steps underlying the survey methodology implemented for the search and consultation of existing literature. In Section 4 (Application), the proposed survey protocol is implemented to a bibliographic analysis on the sustainability. In Section 5 (Discussion), the main methodological and logical-operational evidence of the scientific contributions collected from the literature at the basis of the theoretical assessment framework for sustainable urban projects is illustrated. Finally, in Section 6 (Conclusions) the conclusions of the research are presented.

\section{Method}

The methodological approach for the investigation of the existing literature is aimed at identifying, classifying and examining the most reliable, relevant, up-to-date papers on urban design and the implementation of evaluation models to support the urban interventions of economic, social and environmental sustainability.

The investigation phase of existing literature is developed with a proposed scoping review protocol. It is constituted by four main steps. The definition of these steps is inspired by the Preferred Reporting Items for Systematic Reviews and Meta-Analyses (PRISMA) 
Statement available at http:/ / prisma-statement.org/ (accessed on 3 January 2021). This is a document that consists of a 27-item checklist and a flow-diagram, and aims to guide authors in the development of a systematic review protocol.

The steps of the proposed scoping review protocol are as follows:

Step 1. Construction of the study meta-sample by search queries in most frequently used research tools by the scientific community for bibliographic searches (e.g., Scopus, Web of Science);

Step 2. Studies selection browsing the abstract and keywords of the collected papers;

Step 3. Studies clustering according to the sustainable dimensions;

Step 4. Studies classification on the basis of evaluation methodology and tools implemented in the corresponding case-studies.

Below the description of each 4 step is reported.

\subsection{Step 1: Construction of the Study Meta-Sample with Search Queries in Internet Browsers}

The survey on the existing bibliography is carried out by search queries implemented with the Elsevier Scopus tool. It can be used freely after registering on the corresponding website https: / / www.scopus.com (accessed on 7 January 2021). The search of the bibliographic references to be examined is made with key-words typed in the TITLE-ABS-KEY box on Scopus web-site. With this box it is possible to search title, abstract and keywords of the scientific contributions published in international journals but not listed in the Scopus information catalogue. By consulting the Scopus database, the starting meta-sample of the study is identified.

\subsection{Step 2: Studies Selection}

In order to shorten the meta-sample size in terms of the articles number extracted by Scopus search tool and to identify which of the collected contributions may be of greater scientific significance with respect to the objective underlying the proposed review, the scientific works included in the meta-set are evaluated qualitatively. Each paper and its journal are assessed with bibliometric quality indicators (I). The use of appropriate parameters allows one to make judgments on the scientific contribution value and its impact on the scientific production after the publication date by the journal of affiliation.

The evaluation matrix of the scientific quality performance of the starting metasample is realized. A composite quality indicator (CQI) from the combination of the indicator values at the i-th bibliographic reference is defined. The CQI index of the i-th work is measured by summing each indicator value normalized in the range (0-1). The normalization process is carried out by relating the value of the i-th quality indicator I to the maximum value of the corresponding numerical series referring to the $i$-th bibliographic reference. According to the numerical significance of the CQI index, a decreasing list of the analysis elements is drawn up in terms of scientific relevance.

The identification phase of the scientifically relevant contributions is carried out by comparing the list constructed according to the CQI index with the priority scale proposed by Saaty (1980). The latter is characterized by the identification of increasing numerical values, which is useful to heuristically identify the absolute and relative importance among typologically similar elements. In this case, Saaty's scale is used to identify scientifically relevant publications on urban sustainability. According to Saaty's numerical scale, four ranges are identified (1-3), (3-5), (5-7) and (7-9). Normalizing the extremes of each range with the maximum value in Saaty's scale, the following ranges are obtained: $(0.1-0.3),(0.3-$ $0.5),(0.5-0.7)$ and (0.7-1.0). Each of the four ranges of normalized extremes is associated with a different relevance degree. Table 1 illustrates the degrees of scientific relevance proposed for each of the sub-ranges of numerical definition normalized by Saaty's scale. The relevance degrees are expressed in terms of qualitative judgments ("little relevant", "sufficiently relevant", "very relevant" and "absolutely relevant"). The value ranges in Table 1 are listed in ascending order. 
Table 1. Relevance levels and corresponding values range.

\begin{tabular}{cc}
\hline Values Range & Scientific Relevance Degrees \\
\hline $0.1-0.3$ & Little relevant \\
$0.3-0.5$ & Sufficiently relevant \\
$0.5-0.7$ & Very relevant \\
$0.7-1.0$ & Absolutely relevant \\
\hline
\end{tabular}

According to the indications of Table 1 and the CQI index for i-th contribution, the corresponding scientific relevance degree is identified. So, the real study sample as a basis for the subsequent analyses is defined.

\subsection{Step 2: Studies Clustering}

The output of Step 2 is a preliminary requirement for the cataloguing of articles according to the sustainability aspect (of environmental, economic and social type) most highly evaluated in the i-th study.

The identification of the sustainability type most frequently observed in each of the publications identified after Step 2 is regulated by the use frequency of the keyword "sustainability" with the attributes representing its dimensions ("economic", "social" and "environmental"). The estimation of the keyword frequency is made comparing the times in which the combination of words "economic AND/OR social AND/OR environmental sustainability" is reiterated in the work text.

Three clusters are defined according to the type of sustainability that characterizes the survey works. They can be represented according to a functional interdependence logic carried out by means of the Euler-Venn set theory [39]. Specifically, it is possible to refer to a graphic organization of collected data as in Figure 1.

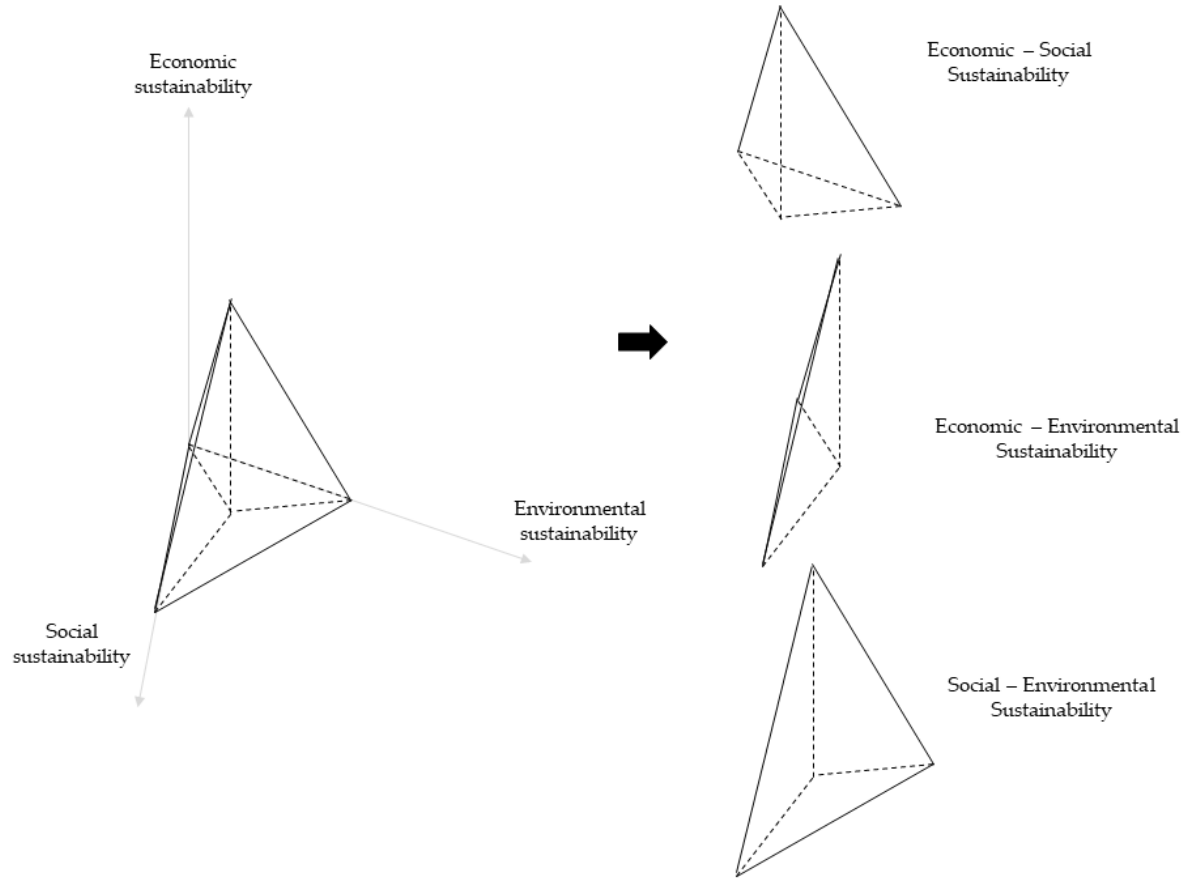

Figure 1. Sustainability tetrahedron and spatially independent sub-units.

Figure 1 illustrates the "sustainability tetrahedron", which is constructed along three main axes, each for a specific dimension of sustainability, on which the relative keyword frequency can be measured. The tetrahedron is composed of three spatially independent sub-domains, which include the bibliographic references characterized by the combination of one, or more, sustainability dimensions. 


\subsection{Step 4: Studies Classification}

Having identified the spatially independent sub-units into which the bibliographic references according to the prevailing sustainability dimension will be included, the works of each domain are classified. Specifically, an information matrix is constructed, in which each reference article is evaluated in terms of (i) specific objective of urban sustainability, (ii) methodology, (iii) tool and (iv) aspects of sustainability explored by the authors in their contribution. The collection of these information types is preparatory to the discussion phase (Section 4) on the main methods and tools used to evaluate urban projects from the sustainable development perspective.

In the next section (Section 3), the results of the implementation of each of the described steps are illustrated.

\section{Application}

4.1. Step 1: Construction of the Study Meta-Sample through Search Queries in Internet Browsers

The construction of the meta sample is carried out with the Scopus search tool, which can be accessed by the corresponding website (accessed on 7 January 2021). In the TITLEABS-KEY box, 6 Key-Words (KW) are textually included: (KW1) "sustainability", (KW2) "urban", (KW3) "renewal" OR "requalification", (KW4) "econom*", (KW5) "models" OR "model" and (KW6) "evaluation" AND/OR "appraisal". Boolean operators (AND-OR) are used to express, respectively, the contemporaneity and surrogacy between some of the key-words considered. The years 2010 to 2020 are the reference time range for the analysis of the existing literature.

Figure 2 shows graphically the result of the bibliographic research obtained through the Scopus search tool. Specifically, the absolute value of the documents is deduced by inserting KW1 in the TITLE-ABS-KEY box of Scopus and progressively adding to it the others taken as reference. This sequence is aimed at guaranteeing a lexical-graphic order and a top-down phenomenal approach. For the purposes of constituting the meta-sample of the study, the $6 \mathrm{KWs}$ are included together. The total number of documents found in the literature is 25 , of which 16 are scientific articles published in indexed journals. As elements of the meta-sample of the study, the 16 papers are taken into account.

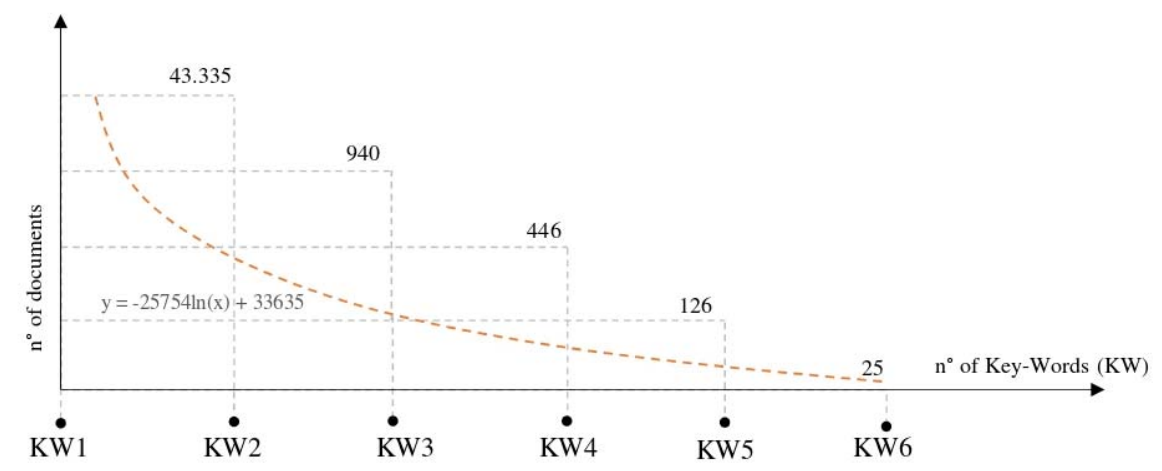

Figure 2. Identification of the meta study sample.

\subsection{Step 2: Studies Selection}

The 16 papers defined with the Step 1 are evaluated from the point of view of quality and impact that the single contribution has scientifically according to the affiliation journal.

Among the quality indicators, the following are taken into account: (i) the citation index (CI) of the i-th paper; (ii) the Scimago Journal Rank (SJR), and (iii) the Source Normalized Impact per Paper (SNPI) of the reference journal. These metrics are taken from the Scopus information system. As reported on the Elsevier website at https:/ / www. elsevier.com (accessed on 7 January 2021) in authors' instruction sector, the (i) is an index of citations among publications, and it allows the user to easily establish which one is more 
cited than another; the (ii) measures the scientific influence degree of academic journals; and the (iii) accounts for field-specific differences in citation practices.

Table 2 shows the evaluation matrix of the scientific quality performance of the starting meta-sample of 16 articles. In addition to the quality indicators considered for each paper of the meta-sample, the year of publication and the journal in which it is published are reported. In Table 3, the composite quality indicator (CQI) index of the i-th paper is computed from the combination of the normalized indicator values in the interval (0-1).

Table 2. Assessment matrix.

\begin{tabular}{|c|c|c|c|c|c|c|}
\hline & Document Title & Year & Source & $\mathrm{CI}$ & $\begin{array}{l}\text { SJR } \\
(2019)\end{array}$ & $\begin{array}{l}\text { SNPI } \\
(2019)\end{array}$ \\
\hline 1 & $\begin{array}{c}\text { Sustainability of urban regeneration projects: novel selection } \\
\text { model based on analytic network process and zero-one goal } \\
\text { programming }\end{array}$ & 2020 & Land Use Policy & 0 & 1.479 & 1.717 \\
\hline 2 & $\begin{array}{c}\text { Policy Framework and Mechanism of Life Cycle Management of } \\
\text { Industrial Land (LCMIL) in China }\end{array}$ & 2020 & Land Use Policy & 0 & 1.479 & 1.717 \\
\hline 3 & $\begin{array}{l}\text { Dynamics of three-dimensional ecological footprint of Zhejiang } \\
\text { coastal zone and its influencing factors based on GTWR model }\end{array}$ & 2020 & $\begin{array}{l}\text { Ying yong sheng tai xue } \\
\text { bao = The Journal of } \\
\text { Applied Ecology }\end{array}$ & 0 & 0.292 & 0.385 \\
\hline 4 & $\begin{array}{l}\text { Identification and evaluation of the renewal of industrial land in } \\
\text { master planning: the case of Lijia, China }\end{array}$ & 2020 & Open House International & 2 & 0.149 & 0.21 \\
\hline 5 & $\begin{array}{c}\text { Privately owned public spaces and regeneration of contexts of } \\
\text { value }\end{array}$ & 2020 & $\begin{array}{l}\text { Journal of Engineering and } \\
\text { Applied Science }\end{array}$ & 0 & 0.101 & 0.032 \\
\hline 6 & $\begin{array}{l}\text { Inheritance or variation? Spatial regeneration and acculturation } \\
\text { via implantation of cultural and creative industries in Beijing's } \\
\text { traditional compounds }\end{array}$ & 2020 & Habitat International & 0 & 1.543 & 2.02 \\
\hline 7 & $\begin{array}{l}\text { The sustainability of urban renewal projects: a model for } \\
\text { economic multi-criteria analysis }\end{array}$ & 2017 & $\begin{array}{l}\text { Journal of Property } \\
\text { Investment and Finance }\end{array}$ & 59 & 0.483 & 1.505 \\
\hline 8 & $\begin{array}{l}\text { Type classification of rural settlements and its consolidation } \\
\text { models based on the coupling of system factor characteristics }\end{array}$ & 2016 & $\begin{array}{l}\text { Beijing Daxue Xuebao } \\
\text { (Ziran Kexue Ban)/Acta } \\
\text { Scientiarum Naturalium } \\
\text { Universitatis Pekinensis }\end{array}$ & 2 & 0.144 & 0.349 \\
\hline 9 & $\begin{array}{l}\text { Renewing bus fleet into diesel plug-in hybrid electric vehicles: } \\
\text { Environmental implications in a medium-size city in Italy }\end{array}$ & 2015 & $\begin{array}{l}\text { WSEAS Transactions on } \\
\text { Environment and } \\
\text { Development }\end{array}$ & 0 & 0.119 & 0.362 \\
\hline 10 & $\begin{array}{l}\text { Ecological network analysis for economic systems: growth and } \\
\text { development and implications for sustainable development }\end{array}$ & 2014 & PLoS ONE & 44 & 1.023 & 1.205 \\
\hline 11 & $\begin{array}{l}\text { A financial appraisal of business improvement districts in the } \\
\text { UK }\end{array}$ & 2014 & $\begin{array}{l}\text { Environment and Planning } \\
\text { C: Government and Policy }\end{array}$ & 3 & 0.998 & 1.573 \\
\hline 12 & $\begin{array}{l}\text { Integrated modelling for sustainability appraisal ofurban river } \\
\text { corridors: going beyond compartmentalised thinking }\end{array}$ & 2013 & Water Research & 10 & 2.932 & 2.542 \\
\hline 13 & $\begin{array}{l}\text { Locally based development tools for identifying opportunities } \\
\text { and evaluating port area strategies of Rijeka }\end{array}$ & 2013 & $\begin{array}{l}\text { Sustainability } \\
\text { (Switzerland) }\end{array}$ & 2 & 0.581 & 1.165 \\
\hline 14 & $\begin{array}{l}\text { Strategic vision of a Euro-Mediterranean port city: A case study } \\
\text { of palermo }\end{array}$ & 2013 & $\begin{array}{l}\text { Sustainability } \\
\text { (Switzerland) }\end{array}$ & 11 & 0.581 & 1.165 \\
\hline 15 & $\begin{array}{l}\text { Scenario analysis for sustainable development of Chongming } \\
\text { Island: water resources sustainability }\end{array}$ & 2012 & $\begin{array}{l}\text { Science of the Total } \\
\text { Environment }\end{array}$ & 34 & 1.661 & 1.977 \\
\hline 16 & $\begin{array}{l}\text { Monitoring trends of urban development and environmental } \\
\text { impact of Beijing, 1999-2006 }\end{array}$ & 2011 & $\begin{array}{l}\text { Science of the Total } \\
\text { Environment }\end{array}$ & 65 & 1.661 & 1.977 \\
\hline
\end{tabular}


Table 3. Standardized assessment matrix.

\begin{tabular}{|c|c|c|c|c|c|c|c|}
\hline & Document Title & Year & Source & CI & $\begin{array}{c}\text { SJR } \\
(2019)\end{array}$ & $\begin{array}{l}\text { SNPI } \\
(2019)\end{array}$ & CQI \\
\hline 1 & $\begin{array}{l}\text { Sustainability of urban regeneration projects: novel } \\
\text { selection model based on analytic network process and } \\
\text { zero-one goal programming }\end{array}$ & 2020 & Land Use Policy & 0.000 & 0.504 & 0.675 & 1.180 \\
\hline 2 & $\begin{array}{l}\text { Policy Framework and Mechanism of Life Cycle } \\
\text { Management of Industrial Land (LCMIL) in China }\end{array}$ & 2020 & Land Use Policy & 0.000 & 0.504 & 0.675 & 1.180 \\
\hline 3 & $\begin{array}{l}\text { Dynamics of three-dimensional ecological footprint of } \\
\text { Zhejiang coastal zone and its influencing factors based } \\
\text { on GTWR model }\end{array}$ & 2020 & $\begin{array}{l}\text { Ying yong sheng tai xue } \\
\text { bao = The journal of } \\
\text { applied ecology }\end{array}$ & 0.000 & 0.100 & 0.151 & 0.251 \\
\hline 4 & $\begin{array}{l}\text { Identification and evaluation of the renewal of } \\
\text { industrial land in master planning: the case of Lijia, } \\
\text { China }\end{array}$ & 2020 & $\begin{array}{l}\text { Open House } \\
\text { International }\end{array}$ & 0.031 & 0.051 & 0.083 & 0.164 \\
\hline 5 & $\begin{array}{l}\text { Privately owned public spaces and regeneration of } \\
\text { contexts of value }\end{array}$ & 2020 & $\begin{array}{l}\text { Journal of Engineering } \\
\text { and Applied Science }\end{array}$ & 0.000 & 0.034 & 0.013 & 0.047 \\
\hline 6 & $\begin{array}{l}\text { Inheritance or variation? Spatial regeneration and } \\
\text { acculturation via implantation of cultural and creative } \\
\text { industries in Beijing's traditional compounds }\end{array}$ & 2020 & Habitat International & 0.000 & 0.526 & 0.795 & 1.321 \\
\hline 7 & $\begin{array}{l}\text { The sustainability of urban renewal projects: a model } \\
\text { for economic multi-criteria analysis }\end{array}$ & 2017 & $\begin{array}{l}\text { Journal of Property } \\
\text { Investment and Finance }\end{array}$ & 0.908 & 0.165 & 0.592 & 1.664 \\
\hline 8 & $\begin{array}{l}\text { Type classification of rural settlements and its } \\
\text { consolidation models based on the coupling of system } \\
\text { factor characteristics }\end{array}$ & 2016 & $\begin{array}{l}\text { Beijing Daxue Xuebao } \\
\text { (Ziran Kexue Ban)/Acta } \\
\text { Scientiarum Naturalium } \\
\text { Universitatis Pekinensis }\end{array}$ & 0.031 & 0.049 & 0.137 & 0.217 \\
\hline 9 & $\begin{array}{c}\text { Renewing bus fleet into diesel plug-in hybrid electric } \\
\text { vehicles: environmental implications in a medium-size } \\
\text { city in Italy }\end{array}$ & 2015 & $\begin{array}{l}\text { WSEAS Transactions for } \\
\text { Environment and } \\
\text { Development }\end{array}$ & 0.000 & 0.041 & 0.142 & 0.183 \\
\hline 10 & $\begin{array}{c}\text { Ecological network analysis for economic systems: } \\
\text { Growth and development and implications for } \\
\text { sustainable development }\end{array}$ & 2014 & PLoS ONE & 0.677 & 0.349 & 0.474 & 1.500 \\
\hline 11 & $\begin{array}{l}\text { A financial appraisal of business improvement districts } \\
\text { in the UK }\end{array}$ & 2014 & $\begin{array}{l}\text { Environment and } \\
\text { Planning C: } \\
\text { Government and Policy }\end{array}$ & 0.046 & 0.340 & 0.619 & 1.005 \\
\hline 12 & $\begin{array}{l}\text { Integrated modelling for sustainability appraisal } \\
\text { ofurban river corridors: going beyond } \\
\text { compartmentalised thinking }\end{array}$ & 2013 & Water Research & 0.154 & 1.000 & 1.000 & 2.154 \\
\hline 13 & $\begin{array}{c}\text { Locally based development-tools for identifying } \\
\text { opportunities and evaluating port area strategies of } \\
\text { Rijeka }\end{array}$ & 2013 & $\begin{array}{l}\text { Sustainability } \\
\text { (Switzerland) }\end{array}$ & 0.031 & 0.198 & 0.458 & 0.687 \\
\hline 14 & $\begin{array}{l}\text { Strategic vision of a Euro-Mediterranean port city: a } \\
\text { case study of Palermo }\end{array}$ & 2013 & $\begin{array}{l}\text { Sustainability } \\
\text { (Switzerland) }\end{array}$ & 0.169 & 0.198 & 0.458 & 0.826 \\
\hline 15 & $\begin{array}{l}\text { Scenario analysis for sustainable development of } \\
\text { Chongming Island: water resources sustainability }\end{array}$ & 2012 & $\begin{array}{l}\text { Science of the Total } \\
\text { Environment }\end{array}$ & 0.523 & 0.567 & 0.778 & 1.867 \\
\hline 16 & $\begin{array}{l}\text { Monitoring trends of urban development and } \\
\text { environmental impact of Beijing, 1999-2006 }\end{array}$ & 2011 & $\begin{array}{l}\text { Science of the Total } \\
\text { Environment }\end{array}$ & 1.000 & 0.567 & 0.778 & 2.344 \\
\hline
\end{tabular}

By combining the CQI index for each article with the range of values summarized in Table 1, the most significant papers were selected. The bibliographic references with a CQI index higher than 0.50 were chosen as the basis for the subsequent analyses. Table 4 shows the eight highly relevant papers, i.e., with a normalized CQI of more than 0.50 in the range $(0-1)$. 
Table 4. Identification of the effective test sample.

\begin{tabular}{|c|c|c|c|}
\hline & Document Title & CQI & $\begin{array}{l}\text { CQI } \\
(0-1)\end{array}$ \\
\hline 1 & $\begin{array}{c}\text { Sustainability of urban regeneration projects: novel selection model based on analytic network process and } \\
\text { zero-one goal programming }\end{array}$ & 1.180 & 1.000 \\
\hline 2 & Policy Framework and Mechanism of Life Cycle Management of Industrial Land (LCMIL) in China & 1.180 & 0.919 \\
\hline 3 & $\begin{array}{c}\text { Dynamics of three-dimensional ecological footprint of Zhejiang coastal zone and its influencing factors } \\
\text { based on GTWR model }\end{array}$ & 0.251 & 0.797 \\
\hline 4 & Identification and evaluation of the renewal of industrial land in master planning: the case of Lijia, China & 0.164 & 0.710 \\
\hline 5 & Privately owned public spaces and regeneration of contexts of value & 0.047 & 0.640 \\
\hline 6 & $\begin{array}{c}\text { Inheritance or variation? Spatial regeneration and acculturation via implantation of cultural and creative } \\
\text { industries in Beijing's traditional compounds }\end{array}$ & 1.321 & 0.563 \\
\hline 7 & The sustainability of urban renewal projects: a model for economic multi-criteria analysis & 1.664 & 0.503 \\
\hline 8 & $\begin{array}{c}\text { Type classification of rural settlements and its consolidation models based on the coupling of system factor } \\
\text { characteristics }\end{array}$ & 0.217 & 0.503 \\
\hline
\end{tabular}

\subsection{Step 3: Studies Clustering}

The actual study sample is analyzed in its specific components. The absolute and relative use frequency of the attributes "economic", "environmental" and "social" in the text body of articles with CQI higher than 0.50 are defined and reported in the following Table 5.

Table 5. Absolute and relative frequencies matrix of the words "economic", "environmental" and "social" in the eight survey articles.

\begin{tabular}{|c|c|c|c|c|c|}
\hline & Document Title & $\begin{array}{l}\text { Total No. of } \\
\text { Words }\end{array}$ & «Economic» & «Environmental» & «Social» \\
\hline \multirow[t]{2}{*}{1} & $\begin{array}{c}\text { Monitoring trends of urban development and environmental } \\
\text { impact of Beijing, 1999-2006 }\end{array}$ & 10,365 & 38 & 80 & 6 \\
\hline & & & $0.37 \%$ & $0.77 \%$ & $0.06 \%$ \\
\hline \multirow[t]{2}{*}{2} & $\begin{array}{l}\text { Integrated modelling for sustainability appraisal ofurban } \\
\text { river corridors: going beyond compartmentalised thinking }\end{array}$ & 7295 & 25 & 23 & 17 \\
\hline & & & $0.34 \%$ & $0.32 \%$ & $0.23 \%$ \\
\hline \multirow[t]{2}{*}{3} & $\begin{array}{l}\text { Scenario analysis for sustainable development of Chongming } \\
\text { Island: water resources sustainability }\end{array}$ & 4766 & 13 & 20 & 3 \\
\hline & & & $0.27 \%$ & $0.42 \%$ & $0.06 \%$ \\
\hline \multirow[t]{2}{*}{4} & $\begin{array}{l}\text { The sustainability of urban renewal projects: a model for } \\
\text { economic multi-criteria analysis }\end{array}$ & 5154 & 11 & 9 & 15 \\
\hline & & & $0.21 \%$ & $0.17 \%$ & $0.29 \%$ \\
\hline 5 & $\begin{array}{c}\text { Ecological network analysis for economic systems: growth } \\
\text { and development and implications for sustainable } \\
\text { development }\end{array}$ & 5410 & 58 & 5 & 3 \\
\hline \multirow{3}{*}{6} & & & $0.97 \%$ & $0.09 \%$ & $0.06 \%$ \\
\hline & $\begin{array}{l}\text { Inheritance or variation? Spatial regeneration and } \\
\text { acculturation via implantation of cultural and creative } \\
\text { industries in Beijing's traditional compounds }\end{array}$ & 10,115 & 11 & 4 & 50 \\
\hline & & & $0.11 \%$ & $0.04 \%$ & $0.49 \%$ \\
\hline 7 & $\begin{array}{l}\text { Sustainability of urban regeneration projects: novel selection } \\
\text { model based on analytic network process and zero-one goal } \\
\text { programming }\end{array}$ & 8875 & 10 & 16 & 17 \\
\hline \multirow{3}{*}{8} & & & $0.11 \%$ & $0.18 \%$ & $0.19 \%$ \\
\hline & $\begin{array}{c}\text { Policy Framework and Mechanism of Life Cycle Management } \\
\text { of Industrial Land (LCMIL) in China }\end{array}$ & 9022 & 16 & 50 & 14 \\
\hline & & & $0.18 \%$ & $0.55 \%$ & $0.16 \%$ \\
\hline
\end{tabular}

Depending on the relative frequency of the adjectives under investigation, the location of the eight papers in the sustainability tetrahedron is identified. The spatial coordinates of each paper are represented by the relative frequencies expressed in percentages in Table 5 . 
Figure 3 illustrates the sustainability tetrahedron with the spatially defined location of the papers under investigation. From the tetrahedron in Figure 3, the clusters of analysis into which publications that take into account one or more aspects of sustainability are extrapolated. On the basis of the semantic clusters thus identified, the eight articles are classified in Step 4 from a methodological-instrumental point of view.

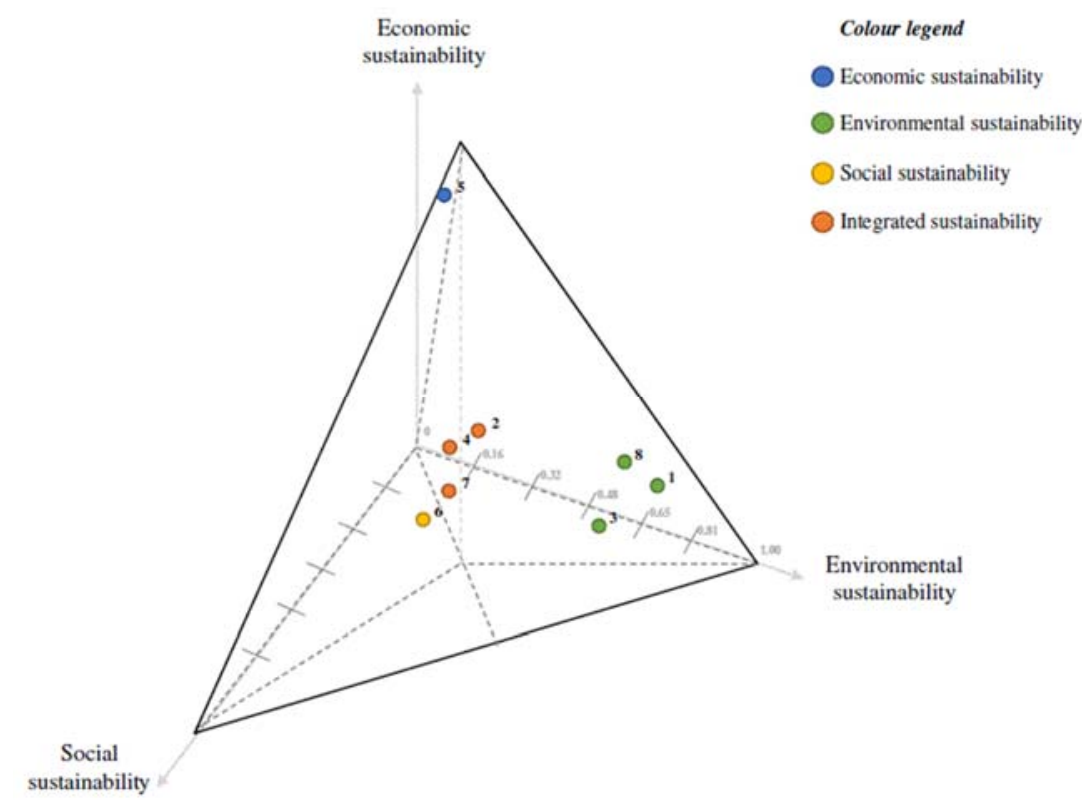

Figure 3. Sustainability clusters.

\subsection{Step 4: Studies Classification}

In Table 7, "Work Aims", "Evaluation Methods", "Operative Tools" and "Analysis Scale" considered in the i-th contribution are briefly reported. Each work is appropriately classified in relation to the prevailing type and/or types of sustainability according to the chromatic legend in Figure 3.

Table 6. Aims, methods, instruments and analysis scales of the eight survey articles.

\begin{tabular}{|c|c|c|c|c|c|c|c|}
\hline & \multirow{2}{*}{ Document Title } & \multirow{2}{*}{ Work Aims } & \multirow{2}{*}{ Evaluation Methods } & \multirow{2}{*}{ Operative Tools } & \multicolumn{3}{|c|}{ Analysis Scale } \\
\hline & & & & & Territorial & City & Urban \\
\hline 1 & $\begin{array}{c}\text { Monitoring trends of } \\
\text { urban development } \\
\text { and environmental } \\
\text { impact in Beijing, } \\
\text { 1999-2006 }\end{array}$ & $\begin{array}{l}\text { To monitor the } \\
\text { negative effects on } \\
\text { human well-being } \\
\text { and ecosystem } \\
\text { integrity in the } \\
\text { urban development } \\
\text { system }\end{array}$ & $\begin{array}{l}\text { Life Cost Analysis for } \\
\text { supply-side } \\
\text { environmental cost } \\
\text { evaluation, including } \\
\text { ecological service supply } \\
\text { and ecological and } \\
\text { economic losses }\end{array}$ & $\begin{array}{c}\text { Emergy-based } \\
\text { sustainability index } \\
\text { as aggregate } \\
\text { measure of the } \\
\text { economic benefit per } \\
\text { unit of } \\
\text { environmental } \\
\text { loading }\end{array}$ & & $\bullet$ & \\
\hline 2 & $\begin{array}{l}\text { Integrated modelling } \\
\text { for sustainability } \\
\text { appraisal ofurban } \\
\text { river corridors: } \\
\text { Going beyond } \\
\text { compartmentalised } \\
\text { thinking }\end{array}$ & $\begin{array}{l}\text { To explore the } \\
\text { benefit of an } \\
\text { integrated modelling } \\
\text { approach to SA and } \\
\text { how a structured } \\
\text { integrated model can } \\
\text { be used to provide a } \\
\text { coherent, consistent } \\
\text { and deliberative } \\
\text { platform to assess } \\
\text { policy or planning } \\
\text { proposals }\end{array}$ & $\begin{array}{l}\text { Sustainability Appraisal } \\
\text { (SA): complex task that } \\
\text { involves integration of } \\
\text { social, environmental } \\
\text { and economic } \\
\text { considerations and often } \\
\text { requires trade-offs } \\
\text { between multiple } \\
\text { stakeholders that may } \\
\text { not easily be brought to } \\
\text { consensus }\end{array}$ & $\begin{array}{l}\text { Bayesian Network: } \\
\text { probabilistic } \\
\text { graphical model that } \\
\text { represents a set of } \\
\text { variables and their } \\
\text { conditional } \\
\text { dependencies via a } \\
\text { directed acyclic } \\
\text { graph }\end{array}$ & & & $\bullet$ \\
\hline
\end{tabular}


Table 7. Aims, methods, instruments and analysis scales of the eight survey articles.

\begin{tabular}{|c|c|c|c|c|c|c|c|}
\hline & \multirow{2}{*}{ Document Title } & \multirow{2}{*}{ Work Aims } & \multirow{2}{*}{ Evaluation Methods } & \multirow{2}{*}{ Operative Tools } & \multicolumn{3}{|c|}{ Analysis Scale } \\
\hline & & & & & Territorial & City & Urban \\
\hline 3 & $\begin{array}{l}\text { Scenario analysis for } \\
\text { sustainable } \\
\text { development of } \\
\text { Chongming Island: } \\
\text { water resources } \\
\text { sustainability }\end{array}$ & $\begin{array}{l}\text { Scenario analysis for } \\
\text { the water resource } \\
\text { management }\end{array}$ & $\begin{array}{l}\text { Multi-objective } \\
\text { evaluation approach }+ \\
\text { multi-level fuzzy logic }\end{array}$ & $\begin{array}{c}\text { Fuzzy } \\
\text { comprehensive } \\
\text { evaluation indices }\end{array}$ & $\bullet$ & & \\
\hline 4 & $\begin{array}{l}\text { The sustainability of } \\
\text { urban renewal } \\
\text { projects: a model for } \\
\text { economic } \\
\text { multi-criteria } \\
\text { analysis }\end{array}$ & $\begin{array}{l}\text { To define a model } \\
\text { for the optimal } \\
\text { allocation of scarce } \\
\text { resources with the } \\
\text { aim of promoting } \\
\text { the sustainable } \\
\text { development of the } \\
\text { territory }\end{array}$ & $\begin{array}{l}\text { Multi-objective and } \\
\text { multi-criteria analysis }+ \\
\text { linear programming } \\
\text { principles }\end{array}$ & Optimization model & & & $\bullet$ \\
\hline 5 & $\begin{array}{l}\text { Ecological network } \\
\text { analysis for } \\
\text { economic systems: } \\
\text { growth and } \\
\text { development and } \\
\text { implications for } \\
\text { sustainable } \\
\text { development }\end{array}$ & $\begin{array}{l}\text { The quantification of } \\
\text { growth and } \\
\text { development in } \\
\text { urban economy of } \\
\text { the city }\end{array}$ & $\begin{array}{l}\text { Ecological network } \\
\text { analysis }\end{array}$ & $\begin{array}{l}\text { System-level indices } \\
\text { to quantify the } \\
\text { growth and } \\
\text { development in } \\
\text { sustainble key }\end{array}$ & & $\bullet$ & \\
\hline 6 & $\begin{array}{c}\text { Inheritance or } \\
\text { variation? Spatial } \\
\text { regeneration and } \\
\text { acculturation via } \\
\text { implantation of } \\
\text { cultural and creative } \\
\text { industries in } \\
\text { Beijing's traditional } \\
\text { compounds }\end{array}$ & $\begin{array}{l}\text { The evaluation of the } \\
\text { cultural impact of } \\
\text { the implantation of } \\
\text { new industries into } \\
\text { historic blocks }\end{array}$ & $\begin{array}{c}\text { Cluster analysis + } \\
\text { Regression analysis }+ \\
\text { questionnaires and } \\
\text { in-depth interviews }+ \\
\text { space syntax }\end{array}$ & $\begin{array}{l}\text { Linear regression } \\
\text { statistical tools }\end{array}$ & & & $\bullet$ \\
\hline 7 & $\begin{array}{l}\text { Sustainability of } \\
\text { urban regeneration } \\
\text { projects: novel } \\
\text { selection model } \\
\text { based on analytic } \\
\text { network process and } \\
\text { zero-one goal } \\
\text { programming }\end{array}$ & $\begin{array}{c}\text { To define a } \\
\text { multi-criteria } \\
\text { evaluation model } \\
\text { capable of selecting } \\
\text { the projects that } \\
\text { must make up an } \\
\text { integrated urban } \\
\text { regeneration } \\
\text { program }\end{array}$ & Multi-criteria analysis & $\begin{array}{l}\text { Analytic newtork } \\
\text { process + zero-one } \\
\text { goal programming }\end{array}$ & & & $\bullet$ \\
\hline 8 & $\begin{array}{l}\text { Policy Framework } \\
\text { and Mechanism of } \\
\text { Life Cycle } \\
\text { Management of } \\
\text { Industrial Land } \\
\text { (LCMIL) in China }\end{array}$ & $\begin{array}{l}\text { Improvement of } \\
\text { industrial land use } \\
\text { for sustainable } \\
\text { urbanization and } \\
\text { smart growth in } \\
\text { urban areas }\end{array}$ & $\begin{array}{l}\text { Life cycle management } \\
\text { analysis }\end{array}$ & $\begin{array}{c}\text { Life Cycle } \\
\text { Management of } \\
\text { Industrial Land } \\
\text { (LCMIL) model on } \\
\text { the basis of the "pre- } \\
\text { plan-do-check-act" } \\
\text { standard }\end{array}$ & & & $\bullet$ \\
\hline
\end{tabular}

\section{Discussion}

The information in Table 7 provides useful references for the construction of a theoretical assessment framework for (i) the analysis, (ii) the evaluation and (iii) the consequent choice of sustainable project initiatives. In light of the results obtained from the application of the proposed survey protocol, it is possible to outline the support of this methodology for the analysis, evaluation and choice of sustainable urban projects. 


\subsection{Analysis}

In the planning, design, implementation and management phases of any type of project, both public and private, the need to analyze the design in a multidimensional manner with respect to the factors that characterize the project's life cycle stages is increasingly recognized. To this end, it is necessary to make use of extensive knowledge that contributes to providing a specific character to the project by examining some of its aspects according to the theoretical-methodological assumptions at the basis of the scientific sector considered and in compliance with the principles of environmental, social and economic sustainability [40]. The contamination and interconnection between multiple disciplines, brought together by the unanimous attempt to pursue the objectives of sustainability, make the system in which it operates highly complex and articulated in terms of subjects and variety of knowledge involved and modus operandi classifiable as unique and generally shared by the operating community.

The elaboration and implementation of methodologies and operational techniques capable of managing with greater accuracy the complexity of reality appears as a central issue to be considered in correspondence of the phases that mark the life cycle of an intervention and the evaluation of its levels of economic, social and environmental sustainability [41].

To acquire an appreciation of the features of design complexity, it is necessary to operate in a city through actions that are planned, designed and implemented with reference to the life of the work conceived in a cyclic, consequential and integrated way $[42,43]$. The adoption of the aspects of life cycle analysis, as well as those of ecological network analysis [44], offers the opportunity to identify the mutual relationships between the elements characterizing the planning, design, construction, management during operation, and possible decommissioning phases that connote the life cycle of a single initiative, and the possibility to assess the adequacy of the solutions adopted with respect to the sustainability objectives regarding the environmental and socio-economic reference context.

\subsection{Evaluation}

The use of appropriate evaluation methods and tools makes it possible to manage an iterative process of control and assessment of the consistency between multidimensional factors characterizing the performance of the project to be implemented in compliance with the sustainability objectives to be pursued. A multiple number of methodological approaches provide answers to different evaluation issues established according to the intervention type and the data on the current frame of the territorial/urban context in which the project operates. With a view to sustainable urban design, assessment methods, such as multi-criteria methods useful for determining preferable and optimal design solutions while simultaneously considering sustainability clusters, provide the opportunity to analyze and choose among the different possible design alternatives the one that best satisfies the criteria, defined according to the assessment problem to be solved and the sustainability objective(s) to be achieved, and the one that performs most efficiently according to the indicators that can measure, quantitatively and/or qualitatively, the levels of urban sustainability after the design initiative [42].

However, the use of multi-criteria methodologies is associated with the operational complexity of jointly considering multiple aspects of the project and the mutual relationships between them during the evaluation phase. The implementation of multi-dimensional methods and techniques often requires a high number of elaborations and, at the same time, the use of logical-operational mechanisms that are often difficult to structure. In order to overcome these difficulties, the construction of evaluation models with an alpha-numeric matrix takes into account the plurality of effects generated by a single project by structuring relations of simple structuring between the problem elements to be solved.

\subsection{Selection of Sustainable Urban Projects}

The use of mathematical models makes evaluation a valuable operational support for the management of complex decision-making systems. This is the case, for example, 
when selecting between alternative intervention programs/projects to be chosen in order to pursue multiple and often conflicting objectives. In order to solve cases characterized by such a level of complexity, both in terms of the interests involved and of the scarcity of resources to be optimally managed, the use of integrated econometric models, which can be structured, for example, in the terms of goal programming (GP), or through the joint use of multi-criteria analysis tools (for example, the analytic network process), allows operators, both public and private, to plan investment programs aimed at ensuring the economic, social and environmental sustainability of the territory in a combined way $[45,46]$.

With regard to GP, in the academic literature of the last decades there has been renewed interest in the development of operational research models, a branch of applied mathematics that includes goal programming models, to solve complex and highly uncertain decision-making processes $[47,48]$. In particular, the need to obtain valuable solutions for conflicting objectives, be they economic, environmental or social, has led to the identification of goal programming as one of the most widely used multi-criteria decision-making techniques [49]. Several studies implemented goal programming for environmental objectives, e.g., to improve the management of public green spaces and for the control of natural water quality [50-53]. Different authors have studied the advantages of goal programming for the selection of investments in territories, with reference to social welfare [54-56], revitalization strategies of historical centers [57,58], allocation of public road funds [59], sustainability of social housing initiatives [60], valorization of public buildings [61-63] and urban renewal projects $[45,64]$.

In recent times, there has been exponential growth of advanced analytics techniques in the reference literature for advanced models capable of processing information collected on trends, preferences, tastes, and social and commercial behaviors of the community, expressed through judgments on the most widely used social networks (Facebook, Twitter, Instagram and so on) [65]. Social media are transparent crowdsourcing platforms [65-69], i.e., heterogeneous data sources, whose effective interpretation, by means of so-called sentiment analysis procedures, can generate models with high predictive capacities regarding changes in consumer preferences following unexpected shocks in the economic and social systems (e.g., the subprime crisis and the ongoing Covid-19 pandemic). Recent studies on advanced analytics techniques highlight the potential of these tools to define resilient urban systems, i.e., systems capable of satisfying the demands of local communities and containing the negative effects brought about by extreme stresses [70-77]. In fact, the analysis of static data, as opposed to a dynamic approach such as that of advanced analytics, does not allow one to achieve resilient solutions that are able to ensure cities' functionality even in unusual conditions [78-86]. The implementation of advanced sentiment analysis models, based on an ongoing monitoring and updating of implementation databases due to community experiences and preferences, can allow for the definition of a holistic model to deal with sudden economic shocks, to interact with the dynamics of urban systems and to play a supporting role for future sustainable urban planning decisions $[77,85,86]$.

\section{Conclusions}

In spite of the fact that sustainable development has been, and still is, an internationally recognized objective for a city' s growth, there is a general operational difficulty in implementing sustainability in concrete actions to be pursued and in criteria to be applied in the evaluation of intervention programs (mid-level) and in urban transformation and territorial growth projects (minimum-level). Especially in the choice of spatial development projects, there is a priority need to use decision support models that allow for (i) specific knowledge of the context in which one intends to act; and (ii) the identification of sustainable design solutions in economic, environmental and social terms. With regard to the latter, the objectives of the United Nations 2030 Agenda, as expressed in the 17 SDGs, and those of the recent European Green New Deal strategy, provide the main framework for the elaboration of new urban planning and design proposals. 
The methodologies and tools of economic evaluation play a crucial role in the process of formulating cost-effective judgments, for example, between alternative design choices, taking into account the relationships existing among multiple aspects and the effects of sustainability generated by the intervention in the reference context [87].

In the framework outlined, the present work aimed to offer an evaluative support, through the definition and implementation of a methodology for the selection of scientific contributions that, better than others, can be adopted for the pursuit of concrete objectives. With reference to the issue of urban sustainability, the articles identified through the application of the methodology developed provide a binding cognitive framework for research and the formulation of innovative logical-operational approaches, as a fundamental reference for an effective analysis and the evaluation and choice of the best performing and most "sustainable" interventions on the territory.

Moreover, it should be noted that the methodology proposed and applied in this work has allowed one to combine the theoretical-methodological contributions developed by researchers operating in different sectors, in order to define a clear and systemic scientific framework for potential public and private users. In this sense, the protocol defined, articulated in four steps that can be easily followed for any practical objective, allows one to adequately enhance the scientific activity of the researchers, where it expresses the complementarity inherent in the ideas and the tools developed in the various papers selected, which will be studied and applied by operators for the definition of effective solutions according to the objective of interest. Of course, the multi-criteria process of assessing the scientific relevance of contributions in the literature has some limitations. These include (i) the collection and review of contributions extracted only from the Scopus motor research; (ii) the use of a small number of scientific quality indicators as inclusion/exclusion criteria of the papers collected by Scopus; and (iii) the implementation of clustering techniques of an empirical and non-logical-mathematical nature, as in the case of the principal component analysis method. The illustrated limitations also provide an opportunity to reflect on the possible research perspectives suggested by this research, in order to apply the logical-operative evidence of the eight papers analyzed in real case studies. This concrete application will allow one to supply operative indications to private and public subjects for the sustainable management projects in urban contexts. Finally, the trial use of innovative techniques, e.g., goal programming and advanced analytics, to support the urban sustainable evaluation, in a separate or integrated manner, should be further explored.

Author Contributions: This research is the result of the joint work of the four authors, to which the work has to be attributed in equal parts. All authors have read and agreed to the published version of the manuscript.

Funding: This research received no external funding.

Institutional Review Board Statement: Not applicable.

Informed Consent Statement: Not applicable.

Data Availability Statement: Data supporting reported analysis results can be found consulting https:/ / www.scopus.com (accessed on 7 January 2021) with the keywords used in the proposed research methodology.

Conflicts of Interest: The authors declare no conflict of interest.

\section{References}

1. Scovronick, N.; Budolfson, M.B.; Dennig, F.; Fleurbaey, M.; Siebert, A.; Socolow, R.H.; Wagner, F. Impact of population growth and population ethics on climate change mitigation policy. Proc. Natl. Acad. Sci. USA 2017, 114, 12338-12343. [CrossRef] [PubMed]

2. Eigenbrod, F.; Bell, V.A.; Davies, H.N.; Heinemeyer, A.; Armsworth, P.R.; Gaston, K.J. The impact of projected increases in urbanization on ecosystem services. Proc. R. Soc. Lond. B Biol. Sci. 2011, 278, 3201-3208. [CrossRef]

3. Di Castri, F. Landscape ecology in a changing globalized environment. Landsc. Ecol. 1997, 12, 3-5. [CrossRef] 
4. Privitera, R. Campagne e Metropoli: Fra Protezione Agricola e Perequazione Urbanistica nei Territori Della Dispersione Insediativa; CreateSpace Independent Publishing Platform: Scotts Valley, CA, USA, 2016; pp. 147-150.

5. Jabareen, Y.R. Sustainable urban forms: Their typologies, models, and concepts. J. Plan. Educ. Res. 2006, 26, 38-52. [CrossRef]

6. Farr, D. Sustainable Urbanism: Urban Design with Nature; John Wiley \& Sons: Hoboken, NJ, USA, 2012.

7. Brundtland, G.H.; Khalid, M.; Agnelli, S.; Al-Athel, S.; Chidzero, B.J.N.Y. Our Common Future; World Commission on Environment and Development: New York, NY, USA, 1987.

8. World Conservation Union/United Nations Environmental Program; The World Wide Fund for Nature. Caring for the Earth: A Strategy for Sustainable Living; IUCN: Gland, Switzerland, 1991.

9. Van Elegem, B.; Embo, T.; Lust, N. A methodology to select the best locations for new urban forests using multicriteria analysis. Forestry 2002, 75, 13-23. [CrossRef]

10. COM/2005/0718 def. Notice from the Commission to the Council and the European Parliament on a Thematic Strategy on the Urban Environment. Available online: https://eur-lex.europa.eu/legal-content/IT/TXT/HTML/?uri=LEGISSUM: 128171\&from $=$ IT (accessed on 25 March 2021).

11. Konijnendijk, C.C.; Nilsson, K.; Randrup, T.B.; Shipperijn, J. Defining urban forestry. A comparative perspective of North America and Europe. Urban For. Urban Green. 2006, 4, 93-103. [CrossRef]

12. Kjell, N.; Sangster, M.; Konijnendijk, C.C. Forests, Trees and Human Health and Well-Being; Springer: Dordrecht, The Netherlands, 2011.

13. European Commission (EC). Directive 2007/2/EC of the European Parliament and of the Council of 14 March 2007 Establishing an Infrastructure for Spatial Information in the European Community. 2007. Available online: https://eur--lex.europa.eu/ legalcontent/EN/TXT/PDF/?uri=CELEX:32007L0002\&from=E (accessed on 23 March 2021).

14. Colglazier, W. Sustainable development agenda: 2030. Science 2015, 349, 1048-1050. [CrossRef] [PubMed]

15. Locurcio, M.; Morano, P.; Tajani, F.; Di Liddo, F. An innovative GIS-based territorial information tool for the evaluation of corporate properties: An application to the Italian context. Sustainability 2020, 12, 5836. [CrossRef]

16. De Paola, P.; Del Giudice, V.; Massimo, D.E.; Forte, F.; Musolino, M.; Malerba, A. Isovalore maps for the spatial analysis of real estate market: A case study for a central urban area of Reggio Calabria, Italy. In Smart Innovation, Systems and Technologies; Bevilacqua, C., Calabro, F., Della Spina, L., Eds.; Springer: Cham, Switzerland, 2018; Volume 100, pp. 402-410.

17. Del Giudice, V.; De Paola, P. Spatial analysis of residential real estate rental market with geo-additive models. In Advances in Automated Valuation Modelling; Springer: Cham, Switzerland, 2017; pp. 155-162.

18. Di Liddo, F.; Morano, P.; Tajani, F.; Torre, C.M. An innovative methodological approach for the analysis of the effects of urban interventions on property prices. Valori E Valutazioni 2020, 26, 25-49.

19. Morano, P.; Rosato, P.; Tajani, F.; Manganelli, B.; Di Liddo, F. Contextualized property market models vs. generalized mass appraisals: An innovative approach. Sustainability 2019, 11, 4896. [CrossRef]

20. Orlando, G.; Selicato, F.; Torre, C.M. The use of GIS as tool to support risk assessment. In Geo-information for Disaster Management; Zlatanova, S., van Oosterom, P., Fendel, E.M., Eds.; Springer: Berlin/Heidelberg, Germany, 2005; pp. 1381-1399.

21. Morano, P.; Tajani, F.; Locurcio, M. GIS application and econometric analysis for the verification of the financial feasibility of roof-top wind turbines in the city of Bari (Italy). Renew. Sustain. Energy Rev. 2017, 70, 999-1010. [CrossRef]

22. Morano, P.; Tajani, F.; Locurcio, M. Land use, economic welfare and property values: An analysis of the interdependencies of the real-estate market with zonal and socio-economic variables in the municipalities of Apulia region (Italy). In Sustainable Infrastructure: Breakthroughs in Research and Practice; Clarke, S., Jennex, Murray E., Anttiroiko, A., Eds.; IGI Global, Information Resources Management Association: Hershey, PA, USA, 2020; Volume 2, pp. 414-437.

23. Bonifazi, A.; Sannicandro, V.; Attardi, R.; Di Cugno, G.; Torre, C.M. Countryside vs city: A user-centered approach to open spatial indicators of urban sprawl. In Computational Science and Its Applications-ICCSA 2016; Lecture Notes in Computer Science; Gervasi, O., Murgante, B., Misra, S., Garau, C., Blecic, I., Taniar, D., Apduhan, B.O., Rocha, A.M.A.C., Tarantino, E., Torre, C.M., et al., Eds.; Springer: Cham, Switzerland, 2016; Volume 9789, pp. 161-176.

24. Colombo, L.; Palomba, I.G.; Sannicandro, V.; Torre, C.M. Geographic data infrastructure and support system to the evaluation of urban densification. In Computational Science and Its Applications-ICCSA 2015; Lecture Notes in Computer Science; Gervasi, O., Murgante, B., Misra, S., Garau, C., Blecic, I., Taniar, D., Apduhan, B.O., Rocha, A.M.A.C., Tarantino, E., Torre, C.M., et al., Eds.; Springer: Cham, Switzerland, 2015; Volume 9157, pp. 330-341.

25. Guarini, M.R.; Locurcio, M.; Battisti, F. GIS-based multi-criteria decision analysis for the "highway in the sky". In Computational Science and Its Applications_ICCSA 2015; Lecture Notes in Computer Science; Gervasi, O., Murgante, B., Misra, S., Garau, C., Blecic, I., Taniar, D., Apduhan, B.O., Rocha, A.M.A.C., Tarantino, E., Torre, C.M., et al., Eds.; Springer: Cham, Switzerland, 2015; Volume 9157, pp. 146-161.

26. Long, X.; Yu, H.; Sun, M.; Wang, X.C.; Klemeš, J.J.; Xie, W.; Wang, C.; Li, W.; Wang, Y. Sustainability evaluation based on the Three-dimensional Ecological Footprint and Human Development Index: A case study on the four island regions in China. J. Environ. Manag. 2020, 265, 110509. [CrossRef] [PubMed]

27. Shah, S.A.A.; Zhou, P.; Walasai, G.D.; Mohsin, M. Energy security and environmental sustainability index of South Asian countries: A composite index approach. Ecol. Indic. 2019, 106, 105507. [CrossRef]

28. Hansuebsai, A.; Kaosod, A.; Kanchanasing, T. A new environmental performance index based on the carbon footprint, VOC emissions, and waste in a printing house. Eng. Rep. 2020, 2, e12165. [CrossRef] 
29. Richter, B.; Behnisch, M. Integrated evaluation framework for environmental planning in the context of compact green cities. Ecol. Indic. 2019, 96, 38-53. [CrossRef]

30. Tokimatsu, K.; Dupuy, L.; Hanley, N. Using genuine savings for climate policy evaluation with an integrated assessment model. Environ. Resour. Econ. 2019, 72, 281-307. [CrossRef]

31. Lind, N. A Development of the Human Development Index. Soc. Indic. Res. 2019, 146, 409-423. [CrossRef]

32. Kalimeris, P.; Bithas, K.; Richardson, C.; Nijkamp, P. Hidden linkages between resources and economy: A “Beyond-GDP" approach using alternative welfare indicators. Ecol. Econ. 2020, 169, 106508. [CrossRef]

33. Pais, D.F.; Afonso, T.L.; Fuinhas, A. Are economic growth and sustainable development converging? Evidence from the comparable Genuine Progress Indicator for Organization for Economic Co-operation and Development Countries. Int. J. Energy Econ. Policy 2019, 9, 202. [CrossRef]

34. Vukoszavlyev, S. The connenction between global innovation index and economic well-being indexes. Appl. Stud. Agribus. Commer. 2019, 13, 87-92. [CrossRef]

35. Salata, S. Towards the Paradigm of 'Eco-systemic Planning'. Ecol. Compat. Urban Plan. 2019, $27-43$.

36. Ribeiro, P.J.G.; Gonçalves, L.A.P.J. Urban resilience: A conceptual framework. Sustain. Cities Soc. 2019, 50, 101625. [CrossRef]

37. Burton, H.V.; Deierlein, G.; Lallemant, D.; Singh, Y. Measuring the Impact of Enhanced Building Performance on the Seismic Resilience of a Residential Community. Earthq. Spectra 2017, 33, 1347-1367. [CrossRef]

38. Vona, M.; Manganelli, B.; Tataranna, S.; Anelli, A. An optimized procedure to estimate the economic seismic losses of existing reinforced concrete buildings due to seismic damage. Buildings 2018, 8, 144. [CrossRef]

39. Gargiulo, F.; Silvestri, S.; Ciampi, M. A clustering based methodology to support the translation of medical specifications to software models. Appl. Soft Comput. 2018, 71, 199-212. [CrossRef]

40. Rizzo, F. Il territorio come organizzazione autopoietica, struttura dissipativa e sistema politico-amministrativo: Una scienza del valore e delle valutazioni. In Dimensione Ecologica e Sviluppo Locale: Problemi di Valutazione; Maciocco, G., Marchi, G., Eds.; Franco Angeli: Milano, Italy, 2020.

41. Kähkönen, K. Level of complexity in projects and its impacts on managerial solutions. Int. Proj. Manag. Assoc. 2008, XXIX, 3.

42. Liu, G.; Yang, Z.; Chen, B.; Ulgiati, S. Monitoring trends of urban development and environmental impact of Beijing, $1999-2006$. Sci. Total Environ. 2011, 409, 3295-3308. [CrossRef]

43. Dai, B.; Gu, X.; Xie, B. Policy Framework and Mechanism of Life Cycle Management of Industrial Land (LCMIL) in China. Land Use Policy 2020, 99, 104997. [CrossRef]

44. Huang, J.; Ulanowicz, R.E. Ecological network analysis for economic systems: Growth and development and implications for sustainable development. PLoS ONE 2014, 9, e100923. [CrossRef]

45. Nesticò, A.; Sica, F. The sustainability of urban renewal projects: A model for economic multi-criteria analysis. J. Prop. Invest. Financ. 2017, 35, 397-409. [CrossRef]

46. Nesticò, A.; Elia, C.; Naddeo, V. Sustainability of urban regeneration projects: Novel selection model based on analytic network process and zero-one goal programming. Land Use Policy 2020, 99, 104831. [CrossRef]

47. Walker, M. Introduction to Genetic Programming; Tech. Np, University of Montana: Missoula, MT, USA, 2001. [CrossRef]

48. Linares, P.; Romero, C. Aggregation of preferences in an environmental economics context: A goal-programming approach. Omega 2002, 30, 89-95. [CrossRef]

49. Caballero, R.; Gómez, T.; Ruiz, F. Goal programming: Realistic targets for the near future. J. Multi Criteria Decis. Anal. 2009, 16, 79-110. [CrossRef]

50. Porterfield, R.L. A goal programming model to guide and evaluate tree improvement programs. For. Sci. 1976, 22, 417-430.

51. Chang, S.J.; Buongiorno, J. A programming model for multiple use forestry. J. Environ. Manag. 1981, 13, 45-58.

52. Hubres, R.J.; Rensi, G. Implications of goal programming in forest resource allocation: Some comments. For. Sci. 1981, 27, 454-459.

53. Chen, H.W.; Chang, N.B. Water pollution control in the river basin by fuzzy genetic algorithm-based multiobjective programming modeling. Water Sci. Technol. 1998, 37, 55-63. [CrossRef]

54. Ben-Shahar, H.; Mazor, A.; Pines, D. Town planning and welfare maximization: A methodological approach. Reg. Stud. 1969, 3, 105-113. [CrossRef]

55. Lee, C. Models in Planning; Pergamon Press: Oxford, UK, 1973.

56. Lee, S.M.; Keown, A.J. Integer goal programming model for urban renewal planning. Urban Syst. 1979, 4, 17-26. [CrossRef]

57. Chang, Y.H.; Wey, W.M.; Tseng, H.Y. Using ANP priorities with goal programming for revitalization strategies in historic transport: A case study of the Alishan Forest Railway. Expert Syst. Appl. 2009, 36, 8682-8690. [CrossRef]

58. Courtney, J.F., Jr.; Klastorin, T.D.; Ruefli, T.W. A goal programming approach to urban-suburban location preferences. Manag. Sci. 1972, 18, 258. [CrossRef]

59. Taplin, J.H.; Qiu, M.; Zhang, Z. Allocation of public road funds by goal programming on multiple criteria. Aust. J. Public Adm. 1995, 54, 58-64. [CrossRef]

60. Morano, P.; Tajani, F. Break Even Analysis for the financial verification of urban regeneration projects. In Applied Mechanics and Materials; Trans Tech Publications Ltd.: Bologna, Italy, 2013; Volume 438, pp. 1830-1835.

61. Manganelli, B.; Tajani, F. Optimised management for the development of extraordinary public properties. J. Prop. Invest. Financ. 2014, 32, 187-201. [CrossRef] 
62. Morano, P.; Tajani, F. The transfer of development rights for the regeneration of brownfield sites. In Applied Mechanics and Materials; Scitec Publications Ltd.: Bologna, Italy, 2013; Volume 409, pp. 971-978.

63. Vona, M. A novel approach to improve the code provision based on a seismic risk index for existing buildings. J. Build. Eng. 2020, 28, 101037. [CrossRef]

64. Anelli, D.; Sica, F. The Financial Feasibility Analysis of Urban Transformation Projects: An Application of a Quick Assessment Model. In Smart Innovation, Systems and Technologies; Bevilacqua, C., Calabro, F., Della Spina, L., Eds.; Springer: Cham, Switzerland, 2020; pp. 462-474.

65. Leykin, D.; Lahad, M.; Aharonson-Daniel, L. Gauging urban resilience from social media. Int. J. Disaster Risk Reduct. 2018, 31, 393-402. [CrossRef]

66. Yoshinaga, N.; Kitsuregawa, M. A self-adaptive classifier for efficient text-stream processing. In COLING 2014: Technical Papers, Proceedings of the COLING 2014-25th International Conference on Computational Linguistics, Dublin, Ireland, 23-29 August 2014; Association for Computational Linguistics, ACL Anthology; Helix Conference Centre at Dublin City University (DCU): Dublin, Republic of Ireland, 2014; pp. 1091-1102.

67. Bruns, A.; Liang, Y.E. Tools and methods for capturing Twitter data during natural disasters. First Monday 2012, 17. [CrossRef]

68. Palmieri, F.; Ficco, M.; Pardi, S.; Castiglione, A. A cloud-based architecture for emergency management and first responders localization in smart city environments. Comput. Electr. Eng. 2016, 56, 810-830. [CrossRef]

69. Manganelli, B.; Vona, M.; De Paola, P. Evaluating the cost and benefits of earthquake protection of buildings. J. Eur. Real Estate Res. 2018, 11, 263-278. [CrossRef]

70. Allam, Z.; Newman, P. Redefining the smart city: Culture, metabolism and governance. Smart Cities 2018, 1, 4-25. [CrossRef]

71. Angelidou, M.; Psaltoglou, A.; Komninos, N.; Kakderi, C.; Tsarchopoulos, P.; Panori, A. Enhancing sustainable urban development through smart city applications. J. Sci. Technol. Policy Manag. 2018, 9, 146-169. [CrossRef]

72. Desouza, K.C.; Flanery, T.H. Designing, planning, and managing resilient cities: A conceptual framework. Cities 2013, 35, 89-99. [CrossRef]

73. Hatuka, T.; Rosen-Zvi, I.; Birnhack, M.; Toch, E.; Zur, H. The political premises of contemporary urban concepts: The global city, the sustainable city, the resilient city, the creative city, and the smart city. Plan. Theory Pract. 2018, 19, 160-179. [CrossRef]

74. Leichenko, R. Climate change and urban resilience. Curr. Opin. Environ. Sustain. 2011, 3, 164-168. [CrossRef]

75. Bruneau, M.; Reinhorn, A. Overview of the resilience concept. In Proceedings of the 8th US National Conference on Earthquake Engineering, San Francisco, CA, USA, 18-22 April 2006; Volume 2040, pp. 18-22.

76. Godschalk, D.R. Urban hazard mitigation: Creating resilient cities. Nat. Hazards Rev. 2003, 4, 136-143. [CrossRef]

77. Zobel, C.W. Representing perceived tradeoffs in defining disaster resilience. Decis. Support Syst. 2011, 50, 394-403. [CrossRef]

78. Meerow, S.; Newell, J.P.; Stults, M. Defining urban resilience: A review. Landsc. Urban Plan. 2016, 147, 38-49. [CrossRef]

79. Soyata, T.; Habibzadeh, H.; Ekenna, C.; Nussbaum, B.; Lozano, J. Smart city in crisis: Technology and policy concerns. Sustain. Cities Soc. 2019, 50, 101566. [CrossRef]

80. Yang, B.; Xu, T.; Shi, L. Analysis on sustainable urban development levels and trends in China's cities. J. Clean. Prod. 2016, 141, 868-880. [CrossRef]

81. Zhang, L.; Sun, X.; Xue, H. Identifying critical risks in Sponge City PPP projects using DEMATEL method: A case study of China. J. Clean. Prod. 2019, 226, 949-958. [CrossRef]

82. DesRoches, R.; Taylor, J. The promise of smart and resilient cities. Bridge 2018, 48, 13-20.

83. Khan, Z.; Anjum, A.; Soomro, K.; Tahir, M.A. Towards cloud based big data analytics for smart future cities. J. Cloud Comput. 2015, 4, 1-11. [CrossRef]

84. Kitchin, R. Making sense of smart cities: Addressing present shortcomings. Camb. J. Reg. Econ. Soc. 2015, 8, 131-136. [CrossRef]

85. Kontokosta, C.E.; Malik, A. The Resilience to Emergencies and Disasters Index: Applying big data to benchmark and validate neighborhood resilience capacity. Sustain. Cities Soc. 2018, 36, 272-285. [CrossRef]

86. Woetzel, J.; Remes, J.; Boland, B.; Lv, K.; Sinha, S.; Strube, G.; Means, J.; Law, J.; Cadena, A.; Von der Tann, V. Smart Cities: Digital Solutions for a More Livable Future; McKinsey Global Institute: New York, NY, USA, 2018; pp. 1-152.

87. Kumar, V.; Rouquette, J.R.; Lerner, D.N. Integrated modelling for Sustainability Appraisal of urban river corridors: Going beyond compartmentalised thinking. Water Res. 2013, 47, 7221-7234. [CrossRef] [PubMed] 